\title{
Metafunction Meaning Realization in Lexicogrammar of Sermon Texts on 'Language and Cultural Month', Kupang Town: A Systemic Functional Linguistic Approach
}

\author{
Magdalena Ngongo, Artha Wacana Christian University \\ Mesakh Dethan, Artha Wacana Christian University \\ Hermyn B. Hyna, Artha Wacana Christian University
}

\begin{abstract}
This paper described metafunction meaning realization in lexicogrammar of sermon texts delivered in churches on May 2017 that was called A Language and Cultural Month. The data informing this study were taken from 38 texts and were analysed based on Systemic Functional Linguistics Approach. The results showed that ideational meaning was realized in transitivity system that covered six process types. It showed that material process was more used than other processes. Exclamation process was least used because of the text type, monologue, and also because of the speakers who were more focused on statements that could be understood and interpreted faithfully by listeners. Interpersonal meaning was realized in mood system in which declarative was more used. This fact indicated that the speakers were more focused on describing facts by using statements forms in which listeners could understand and interpret without arguing verbally. The use of textual metafunction of meaning that discovered in theme in which topical theme was used most than other themes, which denoted that the speakers were more focused on message by using topical. The stresses of subject by using mark theme were limitedly used, which implied that the speakers did not need to re-emphasize the topic as subject since the subject itself was clearly enough stated. Based on the findings, it is suggested that sermons should contain varieties types of process, mood, and theme to make sermons be more interesting and make listeners be more motivated to follow other sermons.
\end{abstract}

Keywords: lexicogrammar; metafunction meaning; sermon texts; systemic

\section{Introduction}

Timor Evangelical churches in 2017 declared May as Language and Cultural Month (LCM) month. This decision was based on I Corinthias 3:11. Referring to this fact, sermon delivered on May should relate to language and cultures. The priests of Timor Evangelical churches delivered sermons that described, suggested, and welcomed congregations to know, understand, and apply God's decree based on context that could make themselves or others to be comfortable. All reflected themes were quoted from Holy Bible. The topics that were stated in sermon every week on May had been decided by the committee.

Therefore, the priests described topics based on contexts where the sermon be delivered. In this case, sermons could be various in uttering. Thus, it was interesting to be studied functionally based on the principal of Systemic Functional Linguistics (SFL) approach. This principle is related to how language be functioned in its context in which Halliday (1985) called as "language that is functional". Referring to LCM context, sermon topics are related to it, including cultural symbols that accompanied the worship.

This context was interested to be studied linguistically, especially how lexicogrammar realized language in metafunction meaning, or in other words, how sermons of metafunction meaning were realized in transitivity, mood, and theme. Sermon texts delivered in churches during May 2017 were the corpus of this study that were analysed based on SFL approach stated by Halliday and Martin (1985, 1994, 2004, 2014), especially language of metafunction meaning. These metafunctions meaning simultaneously were in text. Therefore, it was interesting to be studied. This is related to Brown and Yule (1983:1) who said that "analyzing text means analyzing its language." Relating to the text analysis, Halliday (1985) stated that linguists who described language without considering text was barren and describing text 
without relating to language was empty. Therefore, it was essential and interesting to analyse text. Through texts, many aspects of linguistic function could be studied, such as realization of metafunction meaning in lexicogrammar.

There were numerous researchers that conducted studies related to texts, either to spoken or written texts, such as Halliday (2004), who described that clauses as representation of experience that had function to describe ideas or views. Furthermore, Eggins (1994) found out that lexicogrammar and discourse semantic gave sign to how text be meaningful. In addition, Graber (2001) showed that language that was used in text had roles in social activities. Next, Khalid (2013) discovered that mood system and modality that expressed interpersonal meaning were realized in independent and dependent clauses and all clauses were declarative that described information. Next, Ngongo (2015a) found that experiential meaning was realized in transitivity that used highest number of material process in text than other process types. Moreover, Ngongo (2015b) claimed that interpersonal metafunction meaning in text was aimed to get information and state ideas or views. Another one was Davidse and Vandenbergen (2016) that reviewed and described views of Halliday and other researchers related to interpersonal meaning realization.

These researches supported this study with some of limitation since this study focused on three metafunction meaning realizations in lexicogrammar used in sermon texts. Therefore, the general question that was answered through this study was 'How was metafunction meaning of sermon text realized in lexicogrammar?' Meanwhile, three specific questions were: (1) how was experiential meaning of sermon text realized in transitivity system? (2) How was interpersonal meaning of sermon texts realized in mood system? and (3) How was textual meaning of sermon text realized in theme system?

Based on the research questions, the aim of this study was to analyse and describe how metafunction meaning of sermon texts was realized in lexicogrammar level. Beside its aim, this study also had significances in both implication and application.

\section{Literature Review and Underlying Theory}

There are some researchers that were used to support this study, such as Halliday (1977, 1989, 1994, 2002), Halliday and Hassan (1985), Graber (2001), Khalid (2013), Ngongo (2012, 2014, 2015, 2018), Halliday and Martin (2004, 2014). Additionally, Eggins (1994) found that lexicogrammar and discourse semantic gave sign to how text be meant. Halliday and Hassan (1985) stated that the way to understand language was based on the analysis of text. They described how text and context were related to state a choice of form and meaning. It meant that texts were not only related to language as product and process, but also to language unity. It was also related to context in which based on SFL approach covered field, mood, and tenor. These three parts of context are realized in discourse semantic before realized in lexicogrammar. Halliday (1994) described technically the use of lexicogrammar systemically. This part was important as a base to analyse metafunction meaning since lexicogrammar realized metafunction meaning. Halliday (2014) defined clauses as representation of experience that were functioned to state ideas. Moreover, it was described that the basis of an experience was a process and to understand process in relation to its elements needed to analyse transitivity. Related to the process in transitivity, Parson (2014) discovered that there were significant differences among the use of process types in the use of theme and clauses complexity.

Based on the SFL, especially to the stratification, it was stated that context was realized in discourse semantic, then discourse semantic was realized in lexicogrammar, and lexicogrammar was realized in expression: phonology/graphology (Halliday \& Matthiessen, 2004; Halliday, 2014). SFL analysed language choice in relation to the choice of meaning. In addition, Schleppegrell (2011) stated that each language offered its speakers and listeners a choice to guess meaning.

Discourse semantic covered three metafunction meanings: experiential, interpersonal, and textual. These metafunction meaning were realized in lexicogrammar that covers transitivity 
system realizes experiential metafunction meaning; mood system realizes interpersonal metafunction meaning, and theme realizes textual metafunction of meaning.

This study focused on discourse semantic and lexicogramar. Systemically, this study examined how lexicogrammar of language, namely transitivity, mood, and theme systems. Transitivity system analysed clauses in relation to who did what and to whom it did. Mood system analysed the use of clauses in relation to syntactic function. Then theme system analysed clauses in relation to structure of message.

\section{Methodology}

This study was classified as documentary analysis of descriptive qualitative. As documentary analysis, it analysed sermon texts delivered by priests in churches during the LCM on May 2017. The corpus data were 38 sermon texts collected from priests of Timor Evangelical churches. By applying purposive random sampling technique, there were 15 Christian churches in Kupang city taken as sample. The data were analysed descriptive qualitatively. The results were presented in table and described narratively.

\section{Findings and discussion}

There were 38 texts used to be analyzed. Those sermon texts delivered in 15 churches had the same topics, which each Sunday, the topics were decided by the committee. The topics of sermon texts delivered during May 2017 can be seen in Table 1.

Table 1: Topics of sermon texts

\begin{tabular}{|c|c|c|c|c|}
\hline No. & Day/ Sunday & Theme/ Topic & Reference & Total \\
\hline 1. & 1st Sunday & $\begin{array}{l}\text { God created varieties of } \\
\text { languagenb(I) }\end{array}$ & Genesis 11:1-9 & 9 \\
\hline 2. & 2nd Sunday & Sing and dance for God (II) & Exodus 15:1-21 & 5 \\
\hline 3. & 3rd Sunday & Music for God (III) & Psalms 33:1-9 & 10 \\
\hline 4. & Holy Spirit Day & $\begin{array}{l}\text { Language as a tool of witness (IV) } \\
\text { Cultural varieties as riches in }\end{array}$ & Acts 1:1-11 & 5 \\
\hline 5. & 4th Sunday & Christ's body (V) & I Corinthians 12:13-21 & 9 \\
\hline
\end{tabular}

Table 1 showed five sermon topics delivered by priests in churches during May 2017. These topics of sermon texts were taken from Old and New Testament of Holy Bible. The table also showed the use number of each sermon text. The texts stated were described based on the research questions mentioned previously.

\subsection{Realization of ideational metafunction meanings in transitivity system}

Ideational metafunction meaning of sermon texts covered experiential and logical meaning. This meaning was related to function that was associated with content talking about world. These functions were on the level of text structure, such as on the cohesiveness of text. The cohesive element related to lexical was the example of experiential meaning.

Experiential meaning on the grammatical rank had functions that showed process, participants, and circumstances. It was also realized in transitivity system, which related to the choice of process, participants, and circumstances that were associated to certain process types (Halliday, 1994). Therefore, ideational meaning of sermon texts was realized in transitivity system. Each clause in a text had transitivity value that stated number of core argument (Dixon, 2010). Moreover, it was stated that in grammar, transitivity had basic semantic to know the function of core argument. Referring to that, Halliday and Matthiessen (2004) stated that transitivity was a clause system that influenced not only the verb but also the participants and circumstances. Based on those views, it was clear that there were three important elements that should be studied in order to analyze transitivity, namely process, participants, and circumstances. 


\subsubsection{Process}

Transitivity system of sermon covered six process types, namely material, mental, relational, existential, behavioral, and verbal process. Systemically, process element was realized in verb group. Examples of the data showing the use of six processes are as follows.

1) /// They made megaproject of Babel tower because .../// Topic I from GM, p1 S/ Prt Mat Prs C/ Pr

2) // They worried about varieties // Topic I from GM, p1

S/Pr Ment Prsl Cir

Clause number 1 and 2 had process types, such as make and worry. Other words of process types used in texts were are, praise, tell, etc.

Based on those data, it could be stated that a process element was an important element in transitivity because element process stated valence numbers. Transitivity analysis according to SFL had element as a source that described experiences and relation to process. Table 2 below shows the use number of process types in texts.

Table 2: The use number of process types in texts

\begin{tabular}{|l|c|l|l|l|l|l|}
\hline Process types & Topic I & Topic II & Topic III & Topic IV & Topic V & Total \\
\hline Material Pr. & 304 & 79 & 251 & 102 & 177 & 913 \\
Mental Pr. & 198 & 26 & 214 & 82 & 92 & 612 \\
Verbal Pr. & 101 & 46 & 180 & 69 & 42 & 438 \\
Existential Pr. & 71 & 12 & 96 & 9 & 50 & 238 \\
Relational Pr. & 196 & 82 & 228 & 64 & 169 & 739 \\
Behavioural Pr. & 40 & 44 & 68 & 40 & 47 & 239 \\
\hline Total & 910 & 289 & 1.037 & 366 & 577 & 3179 \\
\hline
\end{tabular}

Table 2 pictured the process types of five sermon topic texts. It showed that there were 3,179 used number process types. Material process was most used in texts (913), followed by relational process (739), metal process (612), verbal process (438), behavioural (239) and existential process (238).

\subsubsection{Material process}

Material process type was mostly used in sermon texts. This indicated that the speakers in expressing their experiences were more emphasized to process of doing and acting. The example of clauses using material process type is as follows.

3) $/ / \mathrm{He}$ then takes tambourine// strike it/ dance and sing ...// (Text topic II GP:2) S/Pr Sir Conj Mat.Prs C/Pr. Mat Prs Pr Bhv Prs Conj Bhv Prs

Example 3 used material process types, namely take and strike and followed by behavioural process type, such as dance and sing.

\subsubsection{Relational process}

Relational process type was the second most-used after material process. The use number of relational process was 738. This signified that priests used this process type to express the experiences by describing thing that was related to characterization and identification. This was related to Halliday and Mattthiessen's (2014) claim: relational clause was a clause that stated characteristics and identification. The example of clauses using relational process is as follows.

\section{4) // Language is God's gift // Topic I from GIO:2) S/Pr Rel Prs.}

Example 4 had one relational process type, is. This process type was used many times with some attributive variations, possessiveness, and circumstances, such as become, like/as, 
have, and tend to. Based on SFL approach, participants as subject in process type, such as language, is called as identified/token, while God's gift is called as identifier/value.

\subsubsection{Mental Proccess}

The use of mental process in sermon text was on the third level after material and existential process in which the total use number was 612. This denoted that the speakers expressed their experience in relation to sense. The example of mental process in clause is as follows.

5) // People listen and understand Gospel's testimony l// (topic IV from GIO:1) S/Pr Ment Prs Conj Ment Prs C/Pr

Example 5 used mental process type, namely listen and understand. Process type listen was perceptive of sensing, whereas understand process was cognitive of sensing. The other use of mental process type were realize, see, look at, like, imagine, believe, etc. The use of process type became the speakers' consideration that listeners were human beings who had the sense of feeling, willing, thinking, and deciding, so that in expressing experience, the speakers used this type many times: 612. This supported the description from Halliday and Matthissen (2014) who described that the use of mental process type could be from some views, starting from mental clauses' properties up to the sense type itself.

\subsubsection{Verbal process}

Verbal process type in sermon texts was clause type of saying. The use of this type in texts was 438 times. Because the text type was monologue, it was found that the use of this type was in the form of narrative and reporting. In the form of sharing experience, verbal process was only viewed by using number. It can be stated that usually, the form of sharing occurred more in dialogues than in monologues. The data of using verbal process type can be seen in the following example.

6) /// He speaks about God's Kingdom /// (Topic IV from GP:1) Pr Vbl Prs Verbiage

Example 6 used a verbal process type: speak. Pronoun He in verbal process type was called sayer; whereas God's Kingdom was called verbiage. Other variations of verbal process type in the example were express, answer, tell, communicate, utter, say, request, ask, and speak.

\subsubsection{Behavioural process}

Behavioural process type had the use number of 239. This was caused by the type of text monologue. This process type was analysed either physically or psychologically. The data of this type is as follows.

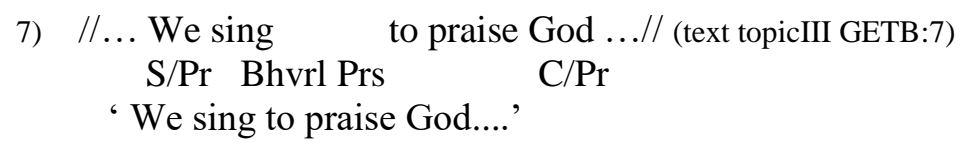

Verbal process sing and praise in example 7 reflected mental and behavioural process. The participant was we, while the main participant, according to (Eggins, 1994), was behaver, but sometimes a behaver was involved.

\subsubsection{Existential process}

The use of existential process in sermon texts was the least use, 236 times. It was only pictured by single element, namely there is/there are. The example of existential process is as follows.

8) /// There are some big problems ... // (Topic II from GEL:1) Exst Prs 
Example 8 included the use of existential process, there is/ there are, and the negative form of it was there is not/there are not.

\subsubsection{Participant}

Participants in sermons were depicted in noun groups. Personal pronoun was a kind of participants accompanying process type. Besides pronoun, vocative was used to reflect participants, such as ladies and gentlemen and God's congregation. The example of clause using vocative (bold letter) can be seen as follows.

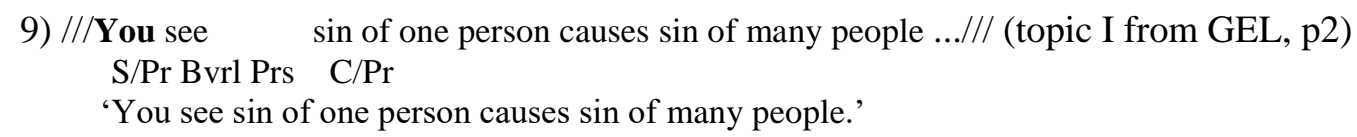

\subsubsection{Circumstance}

Circumstance in transitivity was shown in adverb group and prepositional phrase. The example of circumstance in texts is as follows.

\section{0) // Our worship is done in front of God // (Topic III from GMO:2)}

The bold letters in example 10 were circumstanced as a location. Circumstance element here added more information to a clause, while other circumstances showed manner, reason, etc. The main circumstance types according to Halliday (2004) were location, extent, manner, cause, and contingency.

In broad, process, participant, and circumstance in sermons concerned to how transitivity signified experiential meaning. In fact, priests used variety of process types and more material process to realize experiential meaning. The use of existential process was least used because of text type, monologue, and priests were more focused on statements describing facts that could be understood fully by congregations.

\subsection{Realization of interpersonal meaning in mood systems}

Interpersonal meaning of sermons was displayed in mood systems that covered subject, finite, and other elements of mood structure, namely residue. The function of language according to SFL was exchanging human experience and to have relation and retain interaction with other people. On the level of lexicogrammar, mood system/mood structure had a function of exchanging experience.

Referring to the function of exchanging experience among participants, according to Halliday and Matthiessen (2004), there were two types of speaking roles, namely to ask and to request. Asking something implied that something will be received and requesting something implied that something will be asked as responds. When speakers asked/stated something, listeners responded it verbally - known as dialogue. Whereas in monologue, only speakers exchanged experiences, like in sermon texts.

Sermon texts used mood system in which related to verb form that stated a fact. The fact stated by verb forms could be as indicative (declarative and interrogative form) or imperative. Kinds of clause in mood system, according to Eggins (2007), were declarative, interrogative, and imperative forms. Mood as a system, according to Halliday (2004), had two types: indicative and imperative. Indicative type consisted of declarative and interrogative subtype. Declarative subtype covered exclamatory and affirmative types, while interrogative types covered yes/no and Wh-interrogative. Thus, it can be stated that mood system of sermon texts was described in declarative, interrogative, imperative, and exclamation types. 
Table 3 below presents the use of mood system in sermon.

Table 3: The use mood types in text

\begin{tabular}{|l|c|c|c|c|c|c|}
\hline Mood type & $\begin{array}{c}\text { Topic I } \\
\text { (9 texts) }\end{array}$ & $\begin{array}{c}\text { Topic II } \\
(5 \text { texts) }\end{array}$ & $\begin{array}{c}\text { Topic III } \\
(\mathbf{1 0} \text { texts) }\end{array}$ & $\begin{array}{c}\text { Topic IV } \\
(\mathbf{5} \text { texts })\end{array}$ & $\begin{array}{c}\text { Topic V } \\
(\mathbf{9} \text { texts) }\end{array}$ & $\begin{array}{c}\text { Total } \\
(\mathbf{3 8})\end{array}$ \\
\hline Declarative & 565 & 191 & 608 & 255 & 327 & 1.946 \\
Interrogative & 45 & 10 & 61 & 18 & 28 & 162 \\
Imperative & 25 & 8 & 36 & 10 & 18 & 97 \\
Exclamative & 0 & 2 & 3 & 0 & 2 & 7 \\
\hline Total & 635 & 211 & 708 & 283 & 375 & 2,212 \\
\hline
\end{tabular}

Table 3 displayed the use of mood types in texts. It showed that declarative type was the most-used type than others. This implied that priests were more focused on giving statements because the interpersonal meaning in texts was to give statements that could be understood and thought by congregations without responding verbally. Meanwhile, imperative types were usually used by speakers. This suggested that in sermons of Jesus Christ, He himself in His Gospels used lots of imperative, such as written in New Testament, especially in Gospel of Mathew, chapter 5, 6, 7, 9, 10 and 11.

Grammar of interpersonal meaning in exchanging experiences included subject, predicate/finite, complement, and adjunct. Mood structure, according to Halliday (2004), was a component called mood elements, namely subject, finite, and adjunct modals. Thus, traditionally, it was known as mood clause, whereas mood term, according to Halliday, was related to mood block, consisting of mood and residue. Conjunctions, adjunct, vocative, and expletive were not included mood analysis (Halliday \& Christian, 2004). The data showing the use of mood system and mood structure are simultaneously presented.

\subsubsection{Declarative type - $S^{\wedge} P$}

There were 1,946 numbers of declarative clauses in texts, made it the most-used type than others. The example of declarative is as follows.

11) Topic III GIO: 1)

\begin{tabular}{|l|l|l|}
\hline Music & expels & nervous \\
\hline Subject & Predicate & Com. \\
\hline Mood & Residue & \\
\hline
\end{tabular}

Example 11 was declarative mood type and specifically called as indicative. This example included meaning of exchanging experience to stating an idea. Technically, the mood term, according to Halliday (2004) and Christian (2004), was related to Mood Block that covered mood and residue.

\subsubsection{Interrogative type}

The use of interrogative in sermon texts was at the level two after declarative type. The examples of interrogative clause are as follows.

a. Informative question

12) Topic IV GMO:3 // Why is His name Christ body //

\begin{tabular}{|c|l|l|}
\hline Why is & His name & Christ body \\
\hline Adverb F & S & Comp \\
\hline \multirow{2}{*}{ Residue } & Mood & \multicolumn{1}{c|}{} \\
\cline { 2 - 3 } & &
\end{tabular}

This informative question of example 12 implied direct information that could be understood by congregations without responding verbally. 
b. Polarity question 'yes/no'

13) Topic IV GMO: 1 // Does our language become testimony //

\begin{tabular}{|l|l|l|l|}
\hline Does & our language & becomes & Testimony \\
\hline Adverb & S & P/F & Comp \\
\cline { 2 - 3 } Residue & Mood & \\
\cline { 2 - 3 } & \multicolumn{3}{|l}{} \\
\cline { 2 - 3 }
\end{tabular}

'Does our language become testimony?'

14) Topic III GMO:1 // Ladies and gentlemen/ you like to listen music //

\begin{tabular}{|l|l|l|}
\hline Ladies and gentlemen' & like to listen & Music \\
\hline S & F/P & Comp \\
\hline Mood & \multicolumn{2}{|c|}{ Residue } \\
\hline
\end{tabular}

'Ladies and gentlemen, do you like to listen music?'

Examples 13 and 14 were polarity questions that implied information of yes/no answer. Example 13 was preceded by question form does, while example 14 was preceded by subject ladies and gentlemen and followed by predicate.

\subsubsection{Imperative type}

a. Imperative (exclusive) $-\mathrm{S}$ : none: $\mathrm{P}^{\wedge} \mathrm{C}$

15) //Sing for God // (Topic III GKN:2)

\begin{tabular}{|l|l|}
\hline Sing & for God \\
\hline P/F & Com. \\
\hline Residue & \\
\hline
\end{tabular}

'Please sing for God.'

b. Imperative (inclusive) $--S^{\wedge} \mathrm{P}^{\wedge} \mathrm{C}$

16) // Let us use social media to promote peace ...// Topic IV GMO:2

\begin{tabular}{|c|l|l|l|}
\hline Let us & use & social media & to promote peace..' \\
\hline S & P & C & Adjunct \\
\hline Mood & Residue \\
\hline
\end{tabular}

'Let us use social media to promote peace'

Examples 15 and 16 were imperative clauses. The subject of example 15 was excluded and had residue only, so the pattern is $\mathrm{P}^{\wedge} \mathrm{C}$. For example 16, the subject was stated and the pattern was $\mathrm{S}^{\wedge} \mathrm{P}^{\wedge} \mathrm{C}$.

\subsubsection{Exclamative type: $\mathrm{Ex}^{\wedge} \mathrm{S}^{\wedge} \mathrm{P}$}

Exclamative type was rarely found in texts. There were only seven exclamative type appeared out of 2,212 clauses. The example of exclamative type is as follows.

17) // Naa.., church has responsibility to develop culture // Topic II GMO:3

\begin{tabular}{|c|l|l|l|}
\hline Naah...(exl) & church & Has & duty to develop culture \\
\hline Excl. & S & P & Compl \\
\hline \multirow{3}{*}{ Residue } & Mood & \multicolumn{1}{l}{} \\
\cline { 2 - 3 } &
\end{tabular}

Example 17 was exclamative type with the mark Naaah... Other exclamative type was ooo. The speaker ignored to use of exclamative type but used more affirmative types than other types to exchange their experience and used affirmative to ensure listeners about a fact/idea. In addition, the priests almost did not use any exclamative type.

Based on the use of mood system in texts, it can be said that mood system and mood structure enabled interpersonal metafunction meaning were depicted. The elucidations showed 
that the priests used varieties of mood types, especially more of declarative type to picture interpersonal metafunction meaning.

\subsection{Realization of metafunction textual meaning in theme}

Textual metafunction meaning was related to how participants arranged experiences to choose meaning that stated message in valence done. The most important message was theme. The placement of theme, according to Halliday (1985), was a preceding message element in a clause. In other words, theme was a preceding clause element that occurred early in a clause. Theme prepared local context to develop message in a clause and was a starting point of a clause. Therefore, it meant that theme exceeded message in a clause.

Theme consisted of topical, interpersonal, and textual themes. These themes reflected textual metafunction meaning. Based on the data, priests used these types of themes. More explanation and some data are presented as follows.

\subsubsection{Theme types}

There were three types of themes in texts as mentioned previously. The examples of these types can be seen in these following data.

18) // Congregation praise the Lord... // (Topic II GTK:3)

$$
\text { TT Rheme }
$$

19) ///Dear ladies and gentlemen that are loved by God, Irraeli nation praised Lord .../// Topic II GEL:1

$$
\text { IT TT Rheme }
$$

Examples 18 and 19 had themes as starting point message in clauses. Example 18 had only one theme, whereas example 19 had two themes. The use number of the three types is presented in Table 4.

Table 4: The number of theme types

\begin{tabular}{|l|c|c|c|c|c|c|}
\hline \multirow{2}{*}{ Theme Types } & \multicolumn{7}{|c|}{ Topic of Text } & Total \\
\cline { 2 - 7 } & I ( (9) & II (5) & III (10) & IV (5) & (V) (9) & 38 \\
\hline Topical theme & 475 & 173 & 480 & 203 & 310 & 1.641 \\
Interpersonal & 90 & 29 & 166 & 36 & 57 & 378 \\
theme & 219 & 68 & 177 & 70 & 132 & 666 \\
Textual theme & & & & & & \\
\hline Total theme & 784 & 270 & 823 & 309 & 499 & 2.685 \\
\hline
\end{tabular}

Table 4 showed the number of theme types in which total number of theme was 2.685 . Topical theme was higher (1.641) than interpersonal (378) and textual theme (666). This indicated that priests were so serious to exchange their experience through uttered messages. The aim of the message was to make congregations to pay more attention. Therefore, it could be said that seriousness in stating experience through message in sermons was depicted in the occurrence of topical theme.

The use of interpersonal theme was lesser than topical and textual themes. The example showed that vocative, modal adjunct, and finite elements were limited in use. It was also found that interrogatives were not verbally answered by congregations. It was because of the type of the text-monologue. The variation use of vocative was not much either, such as ladies and gentlemen and $\operatorname{Sir}(s)$. Even so, there were sermons that almost did not include vocative. It also happened to the use of interrogative, modal adjunct, and finite elements. Based on this fact, it could be predicted that in written texts, those terms might not be stated, but in oral texts, they might be.

Based on the most-used of topical theme in texts, it could be said that priests more emphasized message through topical theme as message development. This was supported by Halliday and Matthiessen (2014)'s statement that the common use theme was participant that was realized in noun group.

Clauses in texts had one or more themes, thus, based on the themes number in texts, sermon thematic structure consisted of four varieties. These thematic structures of themes were the way of textual meaning reflected in grammatical of clauses, similar to the structure of 
process types as representation of proposition and proposal. Thematic structure was the structure of semantic in a view that a clause was analysed as message (Halliday, 1994).

\subsubsection{Marked and unmarked themes}

Marked and unmarked themes were spotted in the texts. These themes were in declarative type that was written in adverb group and prepositional phrase. There was no unmarked theme using complements. The use number of marked/unmarked themes is presented in Table 5.

Table 5: The use of marked and unmarked themes in texts

\begin{tabular}{|l|c|c|c|c|c|c|}
\hline \multirow{2}{*}{$\begin{array}{l}\text { Marked/unmarked } \\
\text { theme }\end{array}$} & \multicolumn{7}{|c|}{ Topical theme } & Total \\
\cline { 2 - 7 } & $\mathrm{I}((9)$ & $\mathrm{II}(5)$ & III (10) & IV (5) & (V) $(9)$ & 38 \\
\hline Marked theme & 45 & 17 & 28 & 27 & 22 & 139 \\
Unmarked theme & 430 & 156 & 452 & 176 & 288 & 1.502 \\
\hline Total & 475 & 173 & 480 & 203 & 310 & 1.641 \\
\hline
\end{tabular}

Table 5 showed the number of marked/unmarked themes of topical theme in which the number of unmarked theme was higher than marked theme. This implied that priests did not concern about marked theme because the subject as unmarked theme gave clear messages understood by congregations. The use of marked theme gave additional messages to subject. This was supported by Halliday and Matthiessen (2004)'s statement that unmarked themes, especially declarative clauses, were mostly used in daily conversation.

In daily conversation, element that was functioned as unmarked theme was subject as theme in declarative clauses. The subject was penned in pronoun and noun groups. According to Halliday and Martthiessen (2004), the common form of marked theme in declarative was complement. The example of marked theme is as follows.

20) /// For me, through language and cultural month// we learn about_...// (Topic V GTK:1)

$$
\text { MT TT Rheme }
$$

The underlined words in example 20 marked the themes that were not functioned as subject, but as prepositional phrase. Other mark themes were formulated in adverbial group. This was verified by the statements of Halliday (1995) and Halliday and Matthiessen (2004) that marked themes were not functioned as subject but as adjunct, namely adverbial group and prepositional phrase or complement.

Based on sermon texts, it could be seen how theme system depicted textual metafunction meaning. This indicated that priests used themes as realization of textual meaning in which topical theme was more used than the others. Besides that, in order to emphasize a message, priests used marked theme even though it was the least-used theme.

\section{Conclusion}

Concerning to the discussion, it could be seen how lexicogrammar related to metafunction meaning. It was clearly shown how transitivity system realized experiential meaning. Priests used six type of process, and material process was the most-used process than other processes. The least-used was exclamation process, noted by the type in which speakers were more focused: declarative type. Priests wanted congregation to pay attention to the message so that they could interpret it faithfully.

The use of mood system showed how this system reflected interpersonal meaning. The explanations implied that priests used variety of mood type and in this case, mood type of declarative was mostly used. The use of theme system in texts showed how this system signalled textual meaning. Priests used three types of theme in which topical theme was the most-used theme. Besides that, in order to emphasize the message, the marked theme was used even though it was limited. 
Therefore, it was suggested that priests could use variety of process type in transitivity system and mood type varieties. It was found that interrogative type was least-used type and exclamation type was rarely used. These types were captivating to be used to attract congregations' attention and motivation. When this was compared to Jesus Christ's sermon, Jesus usually used interrogative and exclamation types in His sermons, as stated in New Testament, in Gospel of Mathew 3:7, 6:23, 12:27,51; 16:13; 17:24; 21:31; 22:20; Mark 8:27, 12:9; Luke.3:7, 7:42, 8:25. It also suggested the use variety of themes or more than one theme to make congregations paying more attention. The use of more than one theme was interesting, since it showed thematic structure that could be interpreted wisely by congregations.

Overall, the use of metafunction meaning variation could be an inspiration and motivation for congregation to attend the next Sunday worship. For other researchers, this study could be an inspiration to analyse other research concerning on other aspects in systemic functional linguistic approach.

\section{References}

Brown G., \& Yule G. 1983. Discourse analysis. London: Cambridge University Press.

Christopher, G. 2015. A Lexicogrammar approach to checking quality: Looking at one or two cases of comparative translation.

Dixon, R.M.W. 2010. Basic linguistic theory volume 2: Grammatical topics. New York: Oxford University Press Inc.

Davidse, K., \& Vandenbergen, S.A. 2015. Introduction: The realization of interpersonal Meaning.

Eggins S. 1994. An Introduction to Systemic Functional Linguistics. London: Pinter Publishers.

Grabber, L.Philip. 2001. Context in text. A systemic functional analysis of the parable of the sower. Dissertation. Emory University, Atlanta, United States.

Halliday, M.A.K. 1977. Explorations in the function of language. London: Edward Arnold Ltd.

Halliday, M. A. K. 1985a. Systemic background. In J. D. Benson, \& W. S. Greaves (eds).

Systemic Perspectives on Discourse, Volume 1. Selected Theoretical Papers from the 9th International Systemic Workshop. Norwood, NJ: Ablex Publishing Corporation, 1 15).

Halliday, M.A.K., \& Hassan R. 1989. Language context and text: Aspect of language in a social semiotic perspective. Australia: Deakin University.

Halliday, M.A.K. 1985b. An Introduction to Functional Grammar. London: Edward Arnold

Halliday, M.A.K., \& Martin.J.R, 1993. Writing science and discursive power. London: Falmer Pittsburgh: University of Pittsburgh Press.

Halliday, M.A.K. 1994. An introduction to functional grammar. Edward Arnold, A Member of the Hoddor Headline Group. London Melbourne Auckland.

Halliday, M.A.K. 2002._Linguistic studies of texts and discourse. London: Continuum.

Halliday, M.A.K., \& Matthiensen, Christian M.I.M. 2004. An introduction to functional grammar. New York: Oxford University Press. Inc.

Halliday, M.A.K., \& Matthiensen, Christian M.I.M. 2014. Hallidyan's introduction to functional grammar (4th ed). Routledge. London and New York: Taylor and Francis Group.

Lembaga Alkitab Indonesia. 2002. Cetakan kelima. Jakarta: Lembaga Alkitab Indonesia.

Ngongo, M. 2012. Text mood in waijewa language: A systemic functional linguistic analysis. e-Journal of Linguistics, 6(2).

Ngongo, M. 2013. Teks kette katonga weri kawendo pada masyarakat adat Wewewa di Pulau Sumba: analisis linguistik sistemik fungsional. Dissertation. Universitas Udayana, Denpasar, Indonesia.

Ngongo, M. 2014. A systemic analysis of text theme in waijewa language. Jurnal Pendidikan Bahasa dan Sastra, 15.

Ngongo, M. 2015a. Text transitivity in mathew, new testament of Kupang Malay language. Jurnal Ilmu Pendidikan Bahasa, 2(1).

Ngongo, M. 2015b. Mood System of Text in Gospel of Mark, New Testament of Kupang Malay 
Ngongo, M. 2018. Taxis and logico-semantic relation in undergraduate students'english theses writing text: A systemic functional linguistics approach. Journal of Arts, Sciences and Commerce, 9(2), 146-152.

Parson, D. 2014. An analysis of lexicogrammar in samples from a corpus of science texts. Humanities Review, 19, 107-119.

Swales, J. M. 1990. Genre analysis. Cambridge: Cambridge University Press.

Schleppegrell, M. J. 2011. Systemic functional linguistics: Exploring meaning in language. In J. Gee \& M. Handford (eds.). The Routledge handbook of discourse analysis. London: Routledge, 21-34. 